\title{
Practicality the development of whole language based bahasa indonesia learning
}

\author{
Khurnia Eva Nilasari ${ }^{1}$, Atmazaki ${ }^{2}$, Harris Effendi Thahar ${ }^{3}$, Azwar Ananda ${ }^{4}$ \\ ${ }^{1}$ Balai Diklat Keagamaan Padang, Padang - Indonesia, (khurniaeva@gmail.com) \\ ${ }^{234}$ Universitas Negeri Padang, Padang - Indonesia, (atmazaki@fbs.unp.ac.id)
}

\begin{abstract}
This reasearch is puposed to explain the practicality of whole language based Bahasa Indonesia learning model. The research is administered through the $\mathrm{R} \& \mathrm{D}$. The practicality testing is conducted at MTsN Gunung Pangilun (MTsN A) 46 students, MTsN Lubuk Buaya (MTsN B) 28 students, and MTsN Parak Lawas 38 students. The result of the research is received through an observation of learning process, practicality assessment by a practitioner and students. Based on the data, the practicality of research product which is conducted to the schools show the difference of practicality marks. At MTsN A and C is considered practical, meanwhile MTsN C is considered very practical. In fact, the degree of practiclity is also influenced by the number of students in a classroom. The practicality of research product after practicality testing of collaborated model, build a cooperative learning so that it increases communicative interaction correlation and respective manner among students.
\end{abstract}

Keywords: bahasa indonesia skills, whole language, learning model, cooperative learning

\section{Introduction}

The goal of learning Bahasa Indonesia through listening, speaking, reading, and writing lead students use language to learn, express ideas fluently and clearly, and communicate effectively (Atmazaki, 2013). Text and context are important factors in implementing a language learning. Good or bad text will affect students' success in demonstrating their language skills (Badrasawi, 2017). In language learning it is required text as a medium for students to communicate and speak. In addition, the text is also the target of the end of language learning as the successful implementation of the language it uses. Good text used and produced by students will not be separated from the context of experience and culture that exist in students.

It is argued that context-based learning is necessary for students. Thus, if we look at the scientific approach stage, it can be the strategy for the implementation of language learning that is able to integrate the four skills of listening, speaking, reading and writing comprehensively integrated (Zaim, 2017). With a scientific approach, it is expected impact, skilled students to speak, to communicate in writing and orally in various contexts. Construct their language skills by utilizing their intellectual, social and emotional (Zaidi, 2017); (Patzelt, 1995); (Brockman, 1994). Furthermore, Noah (2013: v) states that in language learning, construct the contextual text is required. 
Learning to understand texts requires complex language skills. Students will need intensive reading skills in order to understand what they are reading. Students also need communicative speaking skills to express the meaning of the text they read. Students also need intensive listening skills in order to understand the content of the texts submitted by other students. Furthermore, students also need writing skills in order to convey the content of the text in the form of written text. Finally, the goal of learning Indonesia language through listening, speaking, reading, and writing will lead students use language to learn, express ideas fluently and clearly, and communicate effectively (Atmazaki, 2013).

Text-based learning makes language learning not only a lesson that trains communication skills by activating and integrating listening, talking, reading, and writing skills, but also training and developing contextual, logical, and contextual thinking skills. The principle of the text-based language learning is putting language as a text that has a function as defender and reflects the ideas, values, and ideologies of the language user.

To streamline text-based language learning, the whole language learning model is used. The whole language learning model is a language learning model that teaches listening, speaking, reading and writing skills in an integrated and holistic way. Whole Language is a language learning approach that provides comprehensive and whole learning that is associated with a dynamically constructivist approach (Goodman, 1986; Weaver, 1992; De Carlo, 1995).

Whole Language is an appropriate text-based learning applied in the curriculum 2013. As Groff (1997) points out; Sodiq (2015: 120); Aghazadeh (2014: 1) that learning makes the text a crucial and whole language called the Real Book approach. Real Books' approach obviously is a radically unorthodox approach to literacy development. This explains that the whole language is an approach which different from the others because it uses the contextual in language learning. Obviously, text is the main medium in language learning. This approach is widely approved and used by schools both locally, regionally and nationally in some countries, such as the United Kingdom, the United States, Australia and New Zealand.

The whole language learning approach is based on social interaction. The learning activities are mostly done by students, because this approach is not teaching how to learn the language, but rather how to speak good and communicative. This will make the learning process become student's centered. Therefore, the whole language approach in addition to having a holistic paradigm, but also student's centered (Gilles, 2006). To build social interaction requires collaborative learning. Collaboration among fellow students helps them to build their language mastery by representing each other's cultures, their experiences, so that they become rich in vocabulary, and it strengthen their language and communication skills (Dixon, 2014). With in-depth collaboration it will assist students in overcoming students' language difficulties. Because in essence, making the skilled students to speak is difficult (Hey, 2015).

\section{Method}

The research method used this research was Research \& Development. The Research \& Development used to develop products in education and learning that have been tested the validity and effectiveness (Borg, 1989; Sugiyono, 2012, 2013; Plomp, 2010). The purpose of research is to test the practicality of research (Borg, 1989; Sugiyono, 2011). The testing of whole language in this research follows development procedure according to Borg and Gall (1989). To obtain practical data, observations, interviews, and questionnaires were questioned by practitioners and students. Observation is done by observing the implementation of learning. Second, the interviews were conducted to practitioners and students, and the three questionnaires to test the practicality of learning models by practitioners and students. 
The subjects of the study were students in Class VII at MTsN Gunung Pangilun Padang, MTsN Lubuk Buaya, and MTsN Parak Lawas. The first class were 46 students from a high-input school and the student was not the underdog grade in the school, but has a high level of competence. Second class was 28 students from the school with medium input, but has a moderate competence, but the class is seeded from the other class. Third class with 38 students from school with low student enrollment and this class is the second best school.

\section{Results and Discussion}

The practical test of Whole Language Based Learning Model Based on three aspects of assessment are (1) observation of learning process; (2) practical of BPG practitioners; and (3) assessment of the practicality of BPG.

Observation of practicality test through observation of learning process done on three test classes. Tests conducted on MTsN located in Padang City. The basis of the third election of MTsN is based on the acquisition of UN on 2015. The three MTsN are MTsN Model Gunung Pangilun with 46 students, MTsN Lubuk Buaya with 28 students and MTsN Parak Lawas with 38 students. This grouping was conducted on seven MTsN Padang City and based on the score of Bahasa Indonesia subjects based on the results of the National Examination (UN) on 2015, MTsN Model Gunung Pangilun representing MTsN which has the highest student competence with the acquisition of Bahasa Indonesia UN 82.96 of 539 students, MTsN Lubuk Buaya representing MTsN which has the competence of middle students with the acquisition of the score Bahasa Indonesia UN 78.15 from 199 students, and MTsN Parak Lawas representing MTsN who have low student competence from the acquisition of Bahasa Indonesia UN score 74.75 from 217 students.

MTsN Model Gunung Pangilun was conducted in Class VII.6 with the teacher Dra. Refniyeti. MTsN Lubuk Buaya is implemented in Class VII.1 with the teacher Dra. An. MTsN Parak Lawas carried out in Class VII.2 with the teacher Afriyeni, S.Pd. Research products were given to the three teachers two weeks before the test was conducted in order to be learned and understood.

Implementation of the learning process conducted in seven meetings with the KD 3.15, KD 4.15, and KD 3.16. The assessment aspect of observation refers to the ability to manage learning in applying syntax. In the assessment of the implementation of learning conducted by the observer. Observer is the teacher of Bahasa Indonesia who also teaches in the test class. Implementation of Bahasa Indonesia learning is conducted in one week 6 hours of learning with allocation $6 \times 45$ minutes. For MTsN Model Gunung Pangilun was conducted with 3 x meetings and each meeting $2 \times$ 45 minutes. For MTsN Lubuk Buaya held 2 x meetings and each meeting 3 x 45 minutes. MTsN Parak Lawas held $3 \times$ meetings and each meeting $2 \times 45$ minutes. Therefore, trials cannot be implemented at the same time for all three test classes. The implementation of MTsN Model Gunung Pangilun and in MTsN Lubuk Buaya were implemented in almost the same time span, from 7 s.d. 21 January 2017 for MTsN Model Gunung Pangilun and 10 till 25 January 2017 for MTsN Lubuk Buaya. In the case of MTsN Parak Lawas implemented from 26 January till 17 February 2017. Furthermore, MTsN Model Gunung Pangilun will be given initials with the name MTsN A, MTsN Lubuk Buaya with initials MTsN B, and MTsN Parak Lawas with initials MTsN C. Table 1. explains the date of trial run for all three test classes. 
Table 1. Time Implementation and Materials of Trial

\begin{tabular}{|c|c|c|c|c|}
\hline \multirow{2}{*}{ Trials } & \multicolumn{3}{|c|}{ Date of Meeting } & \multirow{2}{*}{ Materials } \\
\hline & MTsN A & MTsN B & MTsN C & \\
\hline \multirow{3}{*}{$\begin{array}{l}2 \text { (Meeting } 2 \text { and } \\
\text { 3) }\end{array}$} & 7-1-2017 & $10-1-2017$ & 2-2-2017 & $\begin{array}{l}\text { Definition fable, Characteristics } \\
\text { fable, Man in fable Indonesia, Kind } \\
\text { of fable }\end{array}$ \\
\hline & 10-1-2017 & $11-1-2017$ & $3-2-2017$ & $\begin{array}{c}\text { Intrinsic Aspect of fable, Telling } \\
\text { fable }\end{array}$ \\
\hline & $11-1-2017$ & $17-1-2017$ & $4-2-2017$ & Telling the content of fable \\
\hline & $14-1-2017$ & $18-1-2017$ & $10-2-2017$ & Structure of fable \\
\hline $\begin{array}{l}3 \text { (Meeting } 4 \text { and } \\
5 \text { ) }\end{array}$ & $17-1-2017$ & $24-1-2017$ & $11-2-2017$ & $\begin{array}{l}\text { Determining the terminology and } \\
\text { word in fable, the characteristics of } \\
\text { sentence in fable and determining } \\
\text { the mistakes on fable }\end{array}$ \\
\hline $\begin{array}{l}4 \text { (Meeting } 6 \text { and } \\
7 \text { ) }\end{array}$ & $\begin{array}{l}18-1-2017 \\
21-1-2017 \\
\end{array}$ & $25-1-2017$ & $\begin{array}{l}16-2-2017 \\
17-2-2017 \\
\end{array}$ & Writing fable \\
\hline
\end{tabular}

Here is the result of observation the developing a model of learning Bahasa Indonesia based Whole Language in MTsN A, MTsN B, dan MTsN C:

1. MTsN A. The Practicality of the Development of Whole Language Based Learning Model in MTsN A is conducted in Class VII.6 with 46 students. Observation of learning implementation consists of observation of preliminary activities, core activities, and observation of closing activities. Implementation of learning follows the learning steps that exist in the RPP. The practitioners made observations with seven meetings. After the observation of the learning process by using wholelanguage based learning model then obtained the practicality of the learning model implemented. Observation of the process of implementation of learning is done by observing based on trial. In test 1 conducted with one meeting, in trial 2 was done with two meetings (meeting 2-3), in trial 3 was done with two meetings (meeting 4-5) and in trial 4 was done with two meetings (meeting 67). This is because each syntax consists of five stages implemented with 2 meetings. In the second trial is KD 4.15. The syntax steps in the first meeting are the 1st syntax (journal dialogue, intensive reading/observation, sharing of text content, identifying text characteristics). The meeting of 2 stages of syntax is creative writing. Likewise for the 4 till 5 for KD 3.16. In experiment 3 is KD 3.16 linguistic element about the type of words and sentences in Fable Text conducted with two meetings. The syntactic phase of the first meeting is the 1st syntax till 4 (journal dialogue, intensive reading/observation, sharing of text content, identifying text characteristics). The meeting of 2 stages of syntax is creative writing. In the fourth trial is KD 3.16 write Text Fable also two meetings. The syntactic phase of the first meeting is the 1st syntax till 4 (journal dialogue, intensive reading/observation, sharing of text content, identifying text characteristics). The second meeting of the syntactic stages is creative writing. The results of the assessment by the teacher on the students' skills on retelling the text content is in good score category with the percentage of $80.7 \%$. Assessment of the closing element learning in the fourth trial, assessing the students' writing skills. Assessment indicators refer to BPG. The indicators of the students' text assessment are (1) relevant content to the topic, (2) systematic organization, (3) choice of words, (4) sentences, and (5) EBI. On average the skills of students in writing in good category with the percentage of $78 \%$. However, it still needs to be improved in the writing of sentences and the use of EBI.

2. MTsN B. Practicality of the Development of Whole Language Based Learning Model in MTsN B was conducted in Grade VII.1 totaling 28 students. Observation of learning implementation consists of preliminary activities, core activities, and observation of closing activities. Observation of the learning process conducted was $6 \mathrm{x}$ meetings with four trials. Learning is done on a daytime 
schedule with a one hour duration is 40 minutes. Learning Bahasa Indonesia once a meeting held 3 hours of lessons, face-to-face time is $3 \times 45$ minutes. After the observation of the learning process by using the whole language learning model then obtained the practicality of the learning model implemented. Observation of the process of implementation of learning is done by observing based on trial. In test 1 conducted with one meeting, in trial 2 done with two meetings (meeting 23 ), in trial 3 done with two meetings (meeting 4-5) and in trial 4 done with two meetings (meeting 6-7). This is because each syntax of the whole language-based model consists of five stages implemented with $2 \times$ meetings. In the second trial is KD 4.15. The syntax stages performed at the first meeting are the first syntax till 4 (journal dialogue, intensive reading/observation, sharing of text content, communicating text characteristics). The second meeting of the syntactic stages is creative writing. Likewise, for the 4-5 meetings for KD 3.16, a third trial was conducted. In trial 3 is KD 3.16 linguistic element about the type of words and sentences in Fable Text held with two meetings. The syntactic phase of the first meeting is the first syntax till 4 (journal dialogue, intensive reading/observation, sharing of text content, communicating text characteristics). The second meeting of the syntactic stages is creative writing. In test 4 is KD 3.16 write Text Fable also two meetings. The syntactic phase of the first meeting is the first syntax till 4 (journal dialogue, intensive reading/observation, sharing of text content, communicating text characteristics). The second meeting of the syntactic stages is creative writing. The results of the assessment by the teacher on the students' skills retelling the text content is in the category of very good score with 87.1\% percentage. Assessment of the closing element learning in the fourth trial, assessing students' writing skills. Assessment indicators refer to BPG. The indicators of the students' text assessment are (1) relevant content to the topic, (2) Systematic organization, (3) Choice of Words, (4) Sentences, and (5) EBI. On average the skills of students in writing in either category with percentage of $80 \%$. However, it still needs to be improved in the writing of sentences and the use of EBI.

3. MTsN C. Practicality of Development the Whole Language Based Learning Model in MTsN C in Class VII.2 is 38 students. Observation of learning implementation consists of observation of preliminary activities, core activities, and observation of closing activities. Trial process done four times. Test 1 was conducted with one meeting, in trial 2 conducted with two meetings (meeting 23 ), in trial 3 was conducted with two meetings (meeting 4-5) and in trial 4 was done with two meetings (meeting 6-7). This is due to every syntax of whole language model consisting of five stages implemented with $2 \times$ meeting. In the second trial is KD 4.15. The syntactic phase of the first meeting is the first syntax until 4 (journal dialogue, intensive reading/observation, sharing of text content, communicating text characteristics). The meeting of 2 stages of syntax is creative writing. Likewise for the fourth meeting till 5 for KD 3.16. In trial 3 is KD 3.16 linguistic element about the type of words and sentences in Fable Text held with two meetings. The syntax stage that the first meeting held is the first syntax till 4 (journal dialogue, intensive reading/observation, sharing of text content, communicating text characteristics). The meeting of 2 stages of the syntax is creative writing. In test 4 is KD 3.16 writing Text Fable also two meetings. The syntax stage that the first meeting held is the first syntax till 4 (journal dialogue, intensive reading/observation, sharing of text content, communicating text characteristics). The meeting of 2 stages of syntax is creative writing. Practitioners made observations with seven meetings. After the observation of the learning process by using the whole language learning model, then obtained the practicality of the learning model implemented. Here are the results of observation of each activity in the process of learning implementation for Developing of Whole Language Based Learning Model. Preliminary activities have a practicality percentage score of $86 \%$ and very practical category. This practicality data explains that preliminary activities are carried out in accordance with the steps that have been designed. The preliminary element consisted of $85 \%$ motivation, $90 \%$ apperception, delivering learning indicator $90 \%$, delivering coverage of learning scope $80 \%$ and delivering learning benefit $85 \%$. Assessment of the closing element learning in the fourth trial, assessing 
students' writing skills. Assessment indicators refer to BPG. The indicators of the students' text assessment are (1) relevant content to the topic, (2) systematic organization, (3) choice of words, (4) sentences, and (5) EBI. On average the skills of students in writing in good category with the percentage of $74.4 \%$. However, it still needs to be improved in word choice, sentence writing, and EBI usage

Assessment the practicality of Master's Practice Books by practitioners was conducted by three teachers of Bahasa Indonesia from three different classes from the test class. The three practitioners were (1) Dra. Refniati, teacher of Bahasa Indonesia from MTsN Model Gunung Pangilun, (2) Erlina Erin, teacher of Bahasa Indonesia from MTsN Lubuk Buaya, and (3) Afriyeni, S.Pd. from MTsN Parak Lawas. The results of the practicality of practitioners' evaluation to BPG were read in Table 2.

Table 2. The Result of Practicality BPG By Practitioners

\begin{tabular}{lcccc}
\hline No & Assessment Aspect & Average & $\%$ & Category \\
& & & & \\
1. & Guideline & 4,00 & 80,00 & Valid \\
2. & Goal & 4,33 & 86,67 & Very Valid \\
3. & Sintax & 4,33 & 86,67 & Very Valid \\
4. & Material & 4,33 & 86,67 & Very Valid \\
5. & Students' Exercise & 4,33 & 86,67 & Very Valid \\
6. & Language Use & 4,33 & 86,67 & Very Valid \\
7. & Lay out & 4,00 & 80,00 & Valid \\
8. & Benefit & 4,67 & 93,33 & Very Valid \\
& Total & 34,3 & 686,7 & \\
& Average & 4,29 & 85,83 & Very Valid \\
\hline
\end{tabular}

Table 11 assessment of BPG by practitioners is $85.83 \%$ with a very practical category. This means that the BPG can be implemented by the teacher. The instructions in the book have led teachers to use the book in the learning process. Purpose in accordance with Basic Competence. Syntax can be implemented in Bahasa Indonesia and in accordance with the characteristics of learning Bahasa Indonesia. The learning material is complete and easy to understand. Assessment in accordance with indicators, both knowledge indicators and skills indicators. The language used is easy to understand. Lay out interesting. BPG provides benefits for teachers in preparing the process of learning implementation.

Assessment of practicality Students' Handbook conducted by students through filling instrument in the form of questionnaire. Questionnaires were given to MTsN A, MTsN B, 28, and MTsN C. Here the results of practicality by students.

The practicality test is based on aspects of (a) observation of the learning implementation process, (b) practicability of BPG according to the practitioner, and (c) BPS practicality according to the students. These three tests of practicality show that the score obtained is in the practical and very practical category. 
Tabel 3. The Result of Practicality BPS in MTsN A

\begin{tabular}{llrrrc}
\hline No & Assessment Aspect & \multicolumn{2}{c}{$\%$} & Category \\
& & MTsN A & MTsN B & MTsN C & \\
1. & Guideline & 80,43 & 89,29 & 89,47 & Very Practical \\
2. & Goal & 86,96 & 92,86 & 92,11 & Very Practical \\
3. & Sintax & 91,30 & 92,86 & 86,84 & Very Practical \\
4. & Material & 93,04 & 96,43 & 89,47 & Very Practical \\
5. & Students' Exercise & 86,96 & 92,86 & 89,47 & Very Practical \\
6. & Language Use & 91,30 & 92,86 & 86,84 & Very Practical \\
7. & Lay out & 95,65 & 85,71 & 84,21 & Very Practical \\
8. & Benefit & 86,96 & 92,86 & 92,11 & Very Practical \\
& Average & 89,08 & 91,96 & 88,82 & Very Practical \\
\hline
\end{tabular}

Observation of the learning process was conducted on three classes of three Madrasah. The mention of the three madrasah is stated by MTsN A for MTsN Model Gunung Pangilun, MTsN B for MTsN Lubuk Buaya, and MTsN C for MTsN Parak Lawas.

Based on the observational assessment, the learning process shows that the learning process was done with whole language based learning model has practical score $86,7 \%$ with very practical category in MTsN A, 93,4\% with very practical category in Middle Class and 89,5\% with very practical category. The test results of practicality was done through observation of the ongoing learning process conducted on how the model of learning is done by the teacher and how the students follow the learning. Interaction between teacher and student were done interactively. That is, whole language-based learning model can be practical and implemented in learning activities without conditioned. This is in line with the statement put forward by Akker as quoted by Fauzan (2002) practicality refers to how research products can be used under natural conditions.

Learning Implementation process of Bahasa Indonesia with whole language based learning model implemented naturally by not impose separation of partial language skills. However, the whole language refers to the context of the activities of the language, for example, listening to texts, understanding the content of the whole text, discussing the main ideas of the text, the students not only cultivate the ability to understand and think, but also cultivate their language skills holistically. Teachers on whole language-based language learning emphasize comprehension of language as a whole and at the same time teachers also learn the grammar, vocabulary, and pronunciation (Ling, 2012; Huang, 2014).

Learning Implementation process in collaboration through the use of jigsaw techniques, groups in pairs of two and four, and mind maps make learning oriented to students. Students discover and build their own understanding of the text, students discuss the text in groups, understand the text, learn new material, including grammar and use of words, and give students more choices to learn, for example choosing books they want to read, writing about the topics they want to write, etc. (Freeman and Freeman, 1992: 39; Taylor, 2007; LeDoux, 2007; Ling, 2012).

For Core activities which is a core part in the learning implementation process of whole-language based learning model which is done by syntax stages of journal dialogue, intensive reading, sharing of text content, communicating characteristic of text, and creative writing involves context-based student experience, based on the literacy experienced by the students. That is, language is used in natural rules (Huang, 2014). This makes language learning appealing to students. The syntax of journal, intensive reading, sharing of textual content comes from students' experiences based on text they have read and heard. Next, students will understand the content of the text and communicate it. 
Maddox (2013) and Ling (2012) also suggested that whole languages with context and literacy on core activities significantly demonstrate the practicality of whole language-based learning models.

The practicality of language learning can be influenced by the number of students in one class. The ideal number of students is between 20 till 32 people in one class will make the learning process becomes more maximal (Permendikbud No. 17 of 2017). Various learning models become easier to implement. This shows that the number of students in the whole language class gives influence to the high or low practicality of application of a learning model.

Furthermore, the syntax of whole language-based learning model is easy to implement in the learning process. Nieveen (2010: 94); Nieveen (1999: 127) states the practicality of the product is determined by the ease of use by the user. With ease of use it can improve the quality of learning. As stated by Joyce (2011: 7) the quality of learning is determined by the success of teachers in involving the students in tasks that are loaded with cognitive and social and the teacher is able in the learning process to teach the students in doing the tasks productively. Therefore, the practicality of wholelanguage model-based research products is shown by how teachers can make students active in language.

Teachers in the learning implementation process model research syntax is placing its role in language learning to be a facilitator. As a facilitator the student's ability is greatly influenced by how the facilitator creates an atmosphere of language for students. The ability to communicate effectively to students is influenced by the ability of the teacher to communicate in any communication event in any environment the student is in, so it is important to respect each other mutually respectfully between teachers and students (Wood, 1981: 5; Kyriacou, 2011: 238).

Practicality of research products, the role of teachers as facilitators in the process of learning implementation on realizing in research development of whole-language based learning model. This answer the test results of practicality of the research proved by a very practical assessment in accordance with the percentage of assessment described previously.

The research of the practice of BPG is done by the practitioners of Indonesian language learning. The result of the research on practicality test shows that BPG is assessed with very practical category with percentage $85,83 \%$. Eight aspects of BPG assessment, practitioners provide high scores on the benefits aspects of books that is $93.33 \%$.

BPG can be used well and provide benefits to teachers when students are learning in a structured way. With the materials contained in the BPG then the teacher can help students understand the learning materials and help students achieve learning objectives. Therefore, material in good book development is a material that leads to the development of accuracy, eloquence and appropriation while emphasizing more and helping students master the material they are studying, as Tomlinson (2001: 70) has pointed out "materials will continue to aim at the development of accuracy, fluency and appropriacy while placing more emphasis on helping learners achieve effect". The materials will continue BPG can be used and provide benefits in the learning process of Bahasa Indonesia for students.

The results of research on BPS for the practicality of the book were assessed by the students with very practical category. The practicality of the book is assessed by students from MTsN A with very practical category with $89.8 \%$. Assessment by students from MTsN B with very practical category with $91,96 \%$. Assessment by students from MTsN C was assessed in very practical category with $88.82 \%$. Based on the three assessments conducted by students, obtained the average practicality of BPS is $90.19 \%$ with very practical category. Based on the practicality test of seven indicators in BPS explained that the book is suitable for use in learning Bahasa Indonesia. 


\section{Conclusion}

Learning Bahasa Indonesia is a learning that requires the mastery of knowledge and language. This will be realized if there is a social interaction of students inside and outside the learning process. Based on the needs analysis found the problems with the use of instructional model Bahasa Indonesia. The problem was caused by the insight and understanding of teachers on the instructional models were not maximized and the need for instructional models that can specifically teach four language skills as a whole and integrated. This problem was seen in the preparation of lesson plan, the implementation of instructional process, and instructional activities have not been teaching holistic language skills.

The development of whole language based Bahasa Indonesia learning has three research products were the Model Book, the Teacher's Handbook, and the Student's Handbook. Based on product trial results indicate that the three products have met the criteria of validity, practicality, and effectiveness. Based on the validity test of the Development of whole language based Bahasa Indonesia learning were valid with very valid category. In practical test was done by observation of learning process, practitioner's evaluation to practicality of Teacher's Handbook, and student's evaluation to practicality of Student's Handbook. The results of practicality test showed that the model was very practical.

\section{References}

Abdelhamid. (2006). The Effect of Using the Whole Language Approach on Developing Some Composition Writing Skills in English for Experimental Secondary Students in Egypt http://files.eric.ed.gov/fulltext/ED497775.pdf.

Aghazadeh, Z. ( 2014). A Comparative Study of Iranian EFL Teachers' versus Learners' Perceptions of High School English Textbooks. Advances in Language and Literary Studies Vol. 5 No. 4. http://dx.doi.org/10.7575/aiac.alls.v.5n.4p.1.

Aitchison, J. (2011). Complete Series Bundle RC: The Articulate Mammal: An Introduction to Psycholinguistics (Routledge Classics). London: Routledge.

Ajideh, P. (2014). A Comparative Study of Iranian EFL Teachers' versus Learners' Perceptions of High School English Textbooks. Advances in Language and Literary Studies Vol. 5 No. 4; Agustus 2014. http://dx.doi.org/10.7575/aic.alls.v5n4p.1.

Akhadiah, S, dkk. (1991). Pembinaan Kemampuan Menulis Bahasa Indonesia. Jakarta: Erlangga.

Akker, Jan Van Den. (1999). Principles and Methods of Development Research. In Design Approaches and Tools in Education and Training. Edited by Akker, Jan Van Den etc. Netherlands: Kluwer Academic Publishers.

Alwasilah, C. (2008). Filsafat Bahasa dan Pendidikan. Bandung:Rosdakarya.

Alwi, H. et. Al. (2002). Kamus Besar Bahasa Indonesia. Jakarta:Balai Pustaka.

Anwar, K., \& Arifani, Y. (2016). Task Based Language Teaching: Development of CALL. International Education Studies, 9(6), 168. https://doi.org/10.5539/ies.v9n6p168

Atmazaki. (2013). Implementasi Kurikulum 2013 Mata Pelajaran Bahasa Indonesia : Pola Pikir, Pendekatan Ilmiah, Teks ( Genre ), dan Penilaian Otentik, (68), 15-22.

Atmazaki. (2013). Implementasi Kurikulum 2013 Mata Pelajaran Bahasa Indonesia: Pola Pikir, Pendekatan Ilmiah, Teks (Genre), dan Penilaian Otentik. Proceeding of The International Seminar on Languages and arts. FBS Universitas Negeri Padang http://ejournal.unp.ac.id/index.php/isla/article /view/3962/3193

Badrasawi, K. J. I., Lide, N., Kassim, A., \& Daud, N. M. (2017). THE EFFECTS OF TEST CHARACTERISTICS ON THE HIERARCHICAL ORDER OF, 14(1), 63-82.

Borg and Gall. (1989). Educational Research, An Introduction. New York and London. Longman Inc 
Brockman, Beth. (1994). Whole Language: A Philosophy of Literacy Teaching for Adults, Tool. http://files.eric.ed.gov/fulltext/ED376428.pdf.

Brown, Sam ED dan Everett, Rebecca S. (1990). Activities for Teaching Using the Whole Language Approach. U.S.A.: Charles C Thomas Publisher.

Budiningsih, C Asri. 2005. Belajar dan Pembelajaran. Jakarta: Rineka Cipta.

Campion, Michael A. (2011). Doing Competencies Well: Best Practices In CompetencyModeling. Http://Blogs.Wayne.Edu/Ioadventures/Files/2013/12/ Doing-Competencies-Well-BestPractices.Pdf

Combs, B. (2001). Cooperative Learning. In Models and Strategies for Training Design. Edited by Medsker, Karen L and Holdsworth, Kristina M. Silver Spring: International Society for Performance Improvement.

Creswell. (2008). Educational Research: Planning, Conducting, and Evaluating Quantitative and Qualitative Research (Third Edition). New Jersey: Pearson Prentice Hall.

Daise, L. (1994). Whole Language An Introduction. http://files.eric.ed.gov/fulltext/ED404501.pdf.

De Carlo, Julia E. (1995). Perspective in Whole Language. Boston: Allyn and Bacon.

Dewey, J. (2009). Pendidikan Dasar Berbasis Pengalaman. Jakarta:PT Indonesia Publishing.

Dixon, L. Q., \& Wu, S. (2014). Understanding Language Learning : Interaction Model in Foreign Language Contexts. Malaysian Journal of Learning and Instruction, 11, 23-39. Retrieved from http://mjli.uum.edu.my/images/pdf/11mjli/2understandingg.pdf

Djiwandono, S. (2008). Tes Bahasa: Pegangan bagi Pengajar Bahasa. Jakarta:Indeks.

Dunkin, J. (1986). The International encyclopedia of Teaching and Teacher Education. Oxford:Pergamon Press.

Emilian, E. (2011). Pendekatan Genre-Based dalam Pengajaran Bahasa Inggris:Petunjuk Guru. Bandung:Rizky Press.

Freeman, Y. S., \& Freeman, D. (1992). Whole Language For Second Language Learners. Amerika: United States of Amerika.

Freeman, Y. S., \& Freeman, D. (1998). ESYEFL teaching:Principles for success. Portsmouth. NH: Heinemann Educational Books.

Froese,V. (1991). Itroduction to whole - language teaching and learning.In V.Froese (Ed.),Whole Language: Practice and theory. Needham Height,MA: Allyn and Bacon.

$\mathrm{Fu}, \mathrm{X}$. (2013). An action research report on applying co-operative learning techniques in an intensive english reading class in China. English Language Teaching, 6(10), 17-31. https://doi.org/10.5539/elt.v6n10p17.

Gall, M. D., Gall, J. P., \& Borg, W. R. (2003). The Nature of Education Research. Educational Research: An Introduction. Retrieved from http://psycnet.apa.org/psycinfo/1996-97171-000

Gilles, C. (2006). An Invitation For A Special Issue On Whole Language (Online): International Journal of Progressive Education, Volume 2 (2). http://inased. org/ijpev2n2/gilles2 .htm).

Goodman, Kenneth S. (2005). What's Whole in Whole Language? University of Arizona:RDR Books.

Groof, P. (1997). Journal of the Simplified Spelling Society (Online) 22, 1997/2 p11-15] http://spellingsociety.org/journals/j22/ wholelang.php

Grover, C E. (2013). Well, That Was An Intellectual Dialogue!": How A Whole-School Focus On Improvement Shifts The Substantive Nature Of Classroom Talk. English Teaching: Practice and Critique. Volume 12, Number 2. http://education.waikato.ac.nz/research/files/etpc/files/ 2013 v12n2art7.pdf

Halimah, L. (2005). Pengembangan Model Pembelajaran Bahasa Secara Utuh Untuk Meningkatkan Kompetensi Komunikatif. UPI:Disertasi http://digilib.upi.edu/digitalview.php?digital id=1328.

Han, M. (2015). An empirical study on the application of cooperative learning to English listening classes. English Language Teaching, 8(3), 177-184. https://doi.org/10.5539/elt.v8n3p177.

Hartoko. D. dan Rahmanto. (1986). Pemandu di Dunia Sastra. Yagyakarta: Kanisius. 
Hasani, A. (2005). Ikhwal Menulis. Serang: Universitas Sultan Ageng Tirtayasa Press.

Hayat, B. (2008). Assesment Berbasis Kelas. Badan Litbang Depdiknas: Pusat Penilaian Pendidikan.http://dx.doi.org/10.7575/aiac.alls.v.5n.4p.1.

Hei, K. C., \& David, M. K. (2015). BASIC AND ADVANCED SKILLS THEY DON ' T HAVE : THE CASE OF POSTGRADUATES AND LITERATURE http://mjli.uum.edu.my, 12, 131-150.

Huang, L. Y. (2014). Learning to read with the whole language approach: The teacher's view. English Language Teaching, 7(5), 71-77. https://doi.org/10.5539/elt.v7n5p71.

Indonesia, Kementerian Pendidikan dan Kebudayaan. 2013. Bahasa Indonesia Wahana pengetahuan:BukunGuru/Kementerian Pendidikan dan Kebudayaan. Jakarta:Kementerian Pendidikan dan Kebudayaan.

Irwan, P. (1999). Logika dan Prosedur Penelitian, Pengantar Teori dan Panduan Praktis Penelitian Sosial bagi mahasiswa dan Peneliti Pemula. Jakarta: STIA-LAN.

Joyce, B., Marsha W., and Emily C. (2011). Models of Teaching:Model-model Pengajaran. Edisi 8. Terjemahan oleh Achmad Fawaid dan Ateilla Mirza. Yogyakarta: Pustaka Pelajar

Joyce, B., Marsha W., and Emily C. (2015). Models of Teaching (9th ed.). Terjemahan oleh Rianayati Kusmini dan Pancasari. Yogyakarta: Pustaka Pelajar

Keraf, Gorys. 1988. Komposisi. Ende : Nusa Indah.

LeDoux, A. (2006). Investigating the Implementation of Whole Language: Strengths and Weaknesses. http://files.eric.ed.gov/fulltext/ED496339.pdf.

Lems, K. (1995). Whole language and the ESYEFL classroom. (Report No. FL 022 904) ERIC Document Reproduction Services No. 384210.

Lie, A. (2002). Cooperative Learning; Mempraktikkan Cooperative Learning di Ruang-ruang Kelas. Jakarta:Grasindo.

Ling, P. (2012). The "whole language" theory and its application to the teaching of English reading. English Language Teaching, 5(3), 147-152. https://doi.org/10.5539/elt.v5n3p147

Luxemburg, Jan van Mieke Bal, \& Willem G. Weststeijn. (1992). Pengantar Ilmu Sastra. Jakarta:Gramedia.

Maddox, K., \& Feng, J. (2013). Whole Language Instruction vs. Phonics Instruction: Effect on Reading Fluency and Spelling Accuracy of First Grade Students.

Mahmoud, A. R. A., Sahrir, M. S., \& Osman, R. bt A. H. (2013). Integration of an interactive program in learning Arabic language for Non-Native speakers via virtual tutor. GEMA Online Journal of Language Studies, 13(3), 117-131.

Mahsun. (2014). Teks dalam Pembelajaran Bahasa Indonesia. Jakarta:Raja Grafindo Perkasa.

Marrelli, A. F., Tondora, J., \& Hoge, M. A. (2005). Strategies for developing competency models. Administration and Policy in Mental Health, 32(5-6), 533-561. https://doi.org/10.1007/s10488-0053264-0

Mcclintock, R., Aera, A., \& Roman, T. (2007). Educational Research. Educational Research.

Miles, Matthew B dan Huberman, A Michael. (1994). Qualitative Data Analysis, Second Edition. California: Sage Publication.

Musdi, Edwin.( 2012). "Pengembangan Model Pembelajaran Geometri Berbasis PMR SMPN Kota Padang". Disertasi, Tidak Diterbitkan. Padang: Pogram Pascasarjana UNP.

Nieveen, Nienke. (1999). Prototyping to Reach Product Quality. In Approaches and Tools in Education and Training. Edited by Akker, Jan Van Den etc. Netherlands: Kluwer Academic Publishers.

- (2010). Formative Evaluation In Educational Design Research. In An Introduction to Educational Design Research. Proceedings of the Seminar Conducted at the East China Normal University, Shanghai (PR China), November 23-26, 2007. Edited by Plomp, Tjeerd and Nieveen, Nienkee. Netherlands: SLO Netherlands Institute for Curriculum Development.

Notodiputro, K. A. (2013). Kompetensi Dasar SD/MI. Jakarta: Kemendikbud.

Patzelt. Karen, E. (1995). Principles of Whole Language and Implications for ESL Learners. http://files.eric.ed.gov/fulltext/ED400526.pdf. 
Plomp, T. (2010). Educational Design: Introduction. From Tjeerd Plomp (eds). Educational ETraining System Design: Introduction. Design of Education and Training (in Dutch).Utrecht (the Netherlands): Lemma. Netherland. Faculty of Educational Science andTechnology, University of Twente.

Popkin, D. (1985). Dialogue journals: A way to personalize communication in a foreign language. Foreign Language Annals, 18(2), 152-56. http://onlinelibrary.wiley.com/doi/10.1111/j.19449720.1985.tb01783.x/full.

Purwo, B.K. (1986). Pusparagam Linguistik dan Pengajaran Bahasa. Jakarta: Arcan.

Rahayu, S.H. (1990) Pengetesan Kemampuan Membaca secara Komunikatif. Jakarta: Universitas Indonesia.

Richards, Jack C. (2013) Creativity in language teaching. Irania Journal of Language Teaching Research 1(3), (Oct., 2013) 19-43. www.urmia.ac.ir.ijltr.

Riduwan. (2011). Belajar Mudah Penelitian untuk Guru-Karyawan dan Peneliti Pemula. Bandung: Alfabeta.

Rorabacher, E. Louise and Georgia Dunbar. (1987). Assignment In Exposition. New York: Harper \&Row Publishers.

Routman, R. (1991). Invitations: Changing as teachers and learners K-12. Portsmouth,NH: Heinemann.

Rubin, J. (1975). What the "Good Language Learner" Can Teach Us. TESOL Quarterly, 9(1), 41. https://doi.org/10.2307/3586011

Santoso, A. (2003). Bahasa Politik Pasca Orde Baru. Jakarta:Wedatama Widya Sastra.

Schwarzer, D. (2001). A Qualitative Assessment of a Foreign Language Whole Language Class. Foreign language annals (Online) Vol. 34,(1) http://onlinelibrary.Wiley.com/doi/10.1111/j.194497.

Schwarzer, D. (2001). Whole language in a foreign language class: From theory to practice. Foreign Language Annals, 34(1), 52-59. https://doi.org/10.1111/j.1944-9720.2001.tb02802.x.

Sodiq, S. (2015). Developing Language Learning Textbooks Enriched with Sense of Literacy: The Case of Junior High School in Indonesia. International Education Studies, 8(9), 120-125. https://doi.org/10.5539/ies.v8n9p120

Soekamto, Toeti dan S. W. Udin. (1997). Teori Belajar dan Model-model Pembelajaran. Jakarta: Rineka Cipta.

Stern. H.H. (1983). Fundamental Concepts of Language Teaching. USA. University Press.

Staton, J. (1988). An introduction to dialogue journal communication. In J. Staton, R. W. Shuy J. K. Peyton, and L. Reed (Eds.) Dialogue journal communication: Classroom, linguistic, social, and cognitive Views. NJ: Ablex

Studies, L. (2014). A Comparative Study of Iranian EFL Teachers' versus Learners' Perceptions of High School English Textbooks. Advances in Language and Literary Studies, 5(4). https://doi.org/10.7575/aiac.alls.v.5n.4p.1

$\mathrm{Su}$, Y.-C. (2003). How the Whole Language Approach Using Predictable Strategies Motivates Bilingual Children. Eric, (3), 1-53. Retrieved from papers2://publication/uuid/07CFE64DF3BD-4F6F-9A09-B01B64B1242C.

Sugiyono. (2011). Metode Penelitian Pendidikan (Pendekatan Kuantitatif, Kualitatif, danR \& D). Bandung: Alfabeta.

Suparno, P. (1997).Filsafat Konstruktivisme Pendidikan. Yogyakarya: Kanisius.

Suratinah \& Prakoso T. (2003). Pendekatan Pembelajaran Bahasa dan Sastra Indonesia SD: Mmateri dan Pembelajaran Bahasa Indonesia SD. Jakarta: Universitas Terbuka.

Suriasumantri, J. S. (2005). Filsafat Ilmu Sebuah Pengantar. Jakarta: Pustaka Sinar Harapan.

Tampubolon, DP. (1990). Kemampuan Membaca: Teknik Membaca Efektif dan Efesien. Bandung:Angkasa.

Tarigan, H. G. (1994). Menulis Sebagai Suatu Keterampilan Berbahasa. Bandung: Angkasa.

Tarigan, H. G. (2008). Pengajaran Kompetensi Berbahasa. Bandung:Angkasa.

Tarigan, H.G. (2006). Dasar-dasar Kurikulum Bahasa. Bandung:Angkasa.

Taylor, George R.; And Others. (1992). The Whole Language Approach: Panacea or Myth? http://files.eric.ed.gov/fulltext/ED364828.pdf 
Taylor, M., \& Otinsky, G. (2007). International Journal of Progressive Education, Volume 3 Number 2, 2007 @ 2007 INASED. International Journal, 3(2).

Thahar, H. E. (2008). Menulis Kreatif. Panduan bagi Pemula. Padang:UNP Press.

Tim Penyusun. (2007). Kamus Besar Bahasa Indonesia. Jakarta: Balai Pustaka.

Tomlinson, B. (2001). Teaching English to Speakers of Other Languages: Materials development. Edited Ronald Carter and David Nunan. Cambridge:University Press.

Turula. (2016). What The Good (Digital) Language Learner Can Teach Us. Teaching English with Technology, 16(3), 52-73, http://www.tewtjournal.org.

Vale, D., Scarino, A. \& McKay P. (1991). The Eight Principles of Language Learning,in Pocket all : a users' guide to the teaching of languages and ESL. Carlton: Curriculum Corporation.

Wahab, A. (1991). Isu Linguistik Pengajaran Bahasa dan Sastra. Surabaya:Airlangga University Press.

Wang, P. (2011). The Effect of Computer-Assisted Whole Language Instruction on Taiwanese University Students' English Learning. English Language Teaching, 4(4), 10-20. https://doi.org/10.5539/elt.v4n4p10.

Weaver, C. Diane S. Ianet V. (1990). Understanding Whole Language. Miami University and Emerit: Western Michigan University.

Widiyatmoko, W. A. (2016). Preparation Model of Student Teacher Candidate in Developing Integrative Science Learning. Journal of Education and Human Development, 5(2), 169-177. https://doi.org/10.15640/jehd.v5n2a20

Wood, B. S. (1981). Children and Comunication, Verbal and nonverbal, Language Development. London: Prentice -Hall. Inc. Englewood Clifes. Inc. 07632

Wuryan \& Yufiarti. (2017). The effect of teaching methods and learning styles on capabilities of writing essays on elementary schools students in East Jakarta. Educational Research and Reviews, 12(12), 635-642. https://doi.org/10.5897/ERR2017.3187.

Yamin, M. (2012). Desain Baru Pembelajaran Konstruktivistik. Jakarta: Referensi.

Yule, G. dan Gillian B. (1996). Analisis Wacana. Discourse Analysis. Jakarta:Gramedia.

Yusuf, M. (2011). Asesmen dan Evaluasi Pendidikan. Padang:UNP Press.

Zaidi, Z. (2017). Formal Classroom Observations: Factors That Affect Their Success. English Language Teaching, 10(6), 83. https://doi.org/10.5539/elt.v10n6p83.

Zaim, M. (2017). Implementing Scientific Approach to Teach English at Senior High School in Indonesia. Asian Social Science, 13(2), 33. https://doi.org/10.5539/ass.v13n2p33 